\title{
Increasing Creasing Transparency and Efficiency: An Examination of County Government Note Disclosures
}

\author{
Steve Modlin ${ }^{1}$ \\ ${ }^{1}$ Hope Drive, Greenville, North Carolina, United States \\ Correspondence: Steve Modlin, Hope Drive, Greenville, North Carolina, United States. E-mail: \\ swmodlin@gmail.com
}

Received: April 15, 2016

Accepted: May 15, 2016 Online Published: October 30, 2016

doi:10.5539/par.v5n2p59

URL: http://dx.doi.org/10.5539/par.v5n2p59

\begin{abstract}
Local government financial audits have provided increased transparency into the many transactions that take place over an entire fiscal year. In many of these cases, it can be determined if local governments have followed state laws, observed generally accepted accounting principles, and established proper internal controls. However, implementation of stricter state guidelines and more stringent accounting standards have not eliminated reporting errors. For these reasons, notes that accompany financial statements are not only useful for clarification and information purposes, but also to question various reporting aspects among statements. This study examines the fiscal year 2009 independent auditor findings among note disclosures in professionally administered county governments in North Carolina. Findings indicate numerous reporting problems within a majority of county governments ranging from employee retirement funding to inadequate insurance coverage and unexplained asset amounts. A more involved county manager, more internal staff dedicated to the audit process, and collaboration in auditor selection are all significant in reducing the number of note disclosure errors.
\end{abstract}

Keywords: governmental accounting, cash management, public finance, local government

\section{Introduction}

Financial accountability among local governments continues to be an evolving issue. Elected boards and staff alike continue to struggle with the balance of service maintenance and financial stability. While various budgeting reforms have been introduced to better formulate and implement allocations to programs, agencies, and departments for increased budgetary control, financial audits are becoming a more important tool in verifying resource allocation and use. From an accounting standpoint, local government staff is continually challenged by the numerous transactions taking place during the course of the fiscal year notwithstanding changes within state laws, budget ordinances, and governmental accounting standards board (GASB) requirements. Financial statements provide much information, but certain transactions require additional information to meet the full disclosure principle of generally accepted accounting principles (GAAP).

This article examines county government note disclosures as identified through independent audit findings among county governments in North Carolina. The state requires local governments to have an audit conducted at the end of each fiscal year by a qualified independent auditor that is also a certified public accountant (CPA). Note disclosures or notes to the financial statements provide increased information so that stakeholders can obtain a reasonable expectation of financial position based on unit operations over the previous fiscal year. Findings indicate that a more involved county manager, more people assigned to the audit process, and selection of the external auditor by a combination of elected officials and staff are all significant in reducing note disclosure reporting problems. There was also a significant relationship between finance officer field and the number of reporting problems indicating that specific types of training is more advantageous in both daily accounting and auditing processes.

This exploratory study adds to the evolving literature surrounding local government financial stability practices. First, it solidifies one gap in the literature by examining a specific element within financial reports at the height of the recession and goes even further into financial statements compared to previous findings (Modlin, 2012). Second, it not only examines a critical portion of the financial statements, but examines the role of various personnel as to audit involvement and auditor selection. Third, it demonstrates to readers that there are many aspects of cost allocation such as retirements, purchases, transferred payables, and risks that can not only cost the 
unit as well as taxpayers, but also be influential in credit analyses and subsequently bond ratings. Comprehension of financial reports and the allocation of funds are critical for a plethora of reasons due to continuing questions from various stakeholders which primarily include elected officials, staff, and pertinent interest groups.

\section{Importance of Note Disclosures}

The notes to the financial statements or note disclosures are designed to provide better comprehension of a government's financial position as a result of various transactions. Notes also provide some guidance in understanding exhibit information that is not conclusive based on financial presentations. The notes primarily include information concerning activities involving the primary unit with a description of the government-wide statements, a basis of presentation of fund financial statements, interfund receivables and payables, enterprise fund information, risk exposure, etc. Below is the major GASB topics covered in note disclosures.

I. Summary of significant accounting policies with an inclusion of any GAAP departures

II. Stewardship, compliance, and accountability

III. Detail notes on all activities and funds

IV. Segment information-enterprise funds

V. Individual major component unit disclosures

VI. The nature of the primary government's accountability for related organizations

VII. Summary disclosure of significant contingencies

Government units are rather discretionary as to note disclosure presentations. Some governments choose to expand the topics above into several major categories to provide for a more comprehensive overview. As transparency and GASB standards have increased, so have the notes. It has been determined that it is not unusual for the notes to exceed 30 pages (Ives, Patton, \& Patton, 2013; Ruppel, 2010). Topic I for instance, can have seven sub-categories inclusive of government-wide statement description, description of the component units of the primary government, basis of presentation of all relevant statements, basis of accounting, assets, liabilities, and fund balances, and an explanation of revenues and expenditures/expenses.

To provide an example as to the comprehensive nature of some note disclosures, there could be an illustration associated with a long-term debt exhibit in which the unit lists the date of a certificate of participation issue, the amount paid, and the balance. The same type of information can be listed for note payables in which there was just borrowing from the primary bank of business. Key issues associated with risk management may also be included such as the amount designated for workers' compensation claims, loss prevention insurance, and information regarding the primary health insurance provider. Contingencies can include the audit requirements for grants that are part of intergovernmental programs (Single Audit Act of 1984) along with outstanding contracts for construction costs accounted for in capital project funds.

\subsection{North Carolina Audit Oversight and the Local Government Commission}

The importance of local government finance practices has become an important issue for many state governments. Findings have suggested that practices range from virtually no oversight or assistance to that of an advisory role of how to alleviate fiscal stress and in some rare cases, state intervention with temporary control of local government finances (Cahill \& James, 1992; Honadle, 2003; Honadle, 2004; Kloha, Weissert, \& Kleine, 2005; Coe, 2008). Nearly all of the indicators used by states could be classified under one of 36 categories used by the International City/County Management Association (ICMA) (Groves \& Valente, 2003). With most of the studies, the benchmarks are created using ratios based on audits from previous fiscal years. In Ohio and North Carolina, the state takes some action if local governments failed to meet certain preliminary benchmarks for units of equivalent size (Modlin, 2010).

The North Carolina Local Government Commission (LGC), the oversight body in this case, is responsible for financial oversight of all local government entities within the state. The LGC has two major levels of review of local government reports. The primary level of review consists of 'unit letters' that cite units for traditional benchmark violations such as low fund balance levels compared to equivalent units, negative quick ratios, negative fund balance levels and internal control problems (Coe, 2007). However, the initial level of review, the focus of the study, is through the dissemination of "white letters" to units citing irregularities and reporting errors within the financial statements. The "white letters" provide very specific accounting problems within the government-wide statements, fund statements, note disclosures, and detailed supplemental schedules as well as the opinion letter (Modlin, 2012). Addressing the issues in the "white letters" is usually the responsibility of local 
government administrators, more specifically the finance officer. Usually employees within the finance office or accounting office (if there are separate departments) make the necessary changes prior to resubmission. These letters are mainly to ensure compatibility among financial statements, increased clarification between statements, to determine if units are following Generally Accepted Accounting Principles (GAAP), and adherence to Governmental Accounting Standards Board (GASB) requirements.

The audit process in North Carolina has many stages and is rather extensive. North Carolina general statutes require that the audit be performed by a certified public accountant or an accountant certified by the North Carolina Local Government Commission (LGC). For counties that are soliciting services regionally or statewide, a highly structured competitive bidding process is required for Request for Proposal (RFP) distribution to potential bidders inclusive of the scope of the audit, a familiarity of state reporting requirements, itemized costs, experience with local government audits, disclosures in the public interest, etc. The audit is executed through a financial and compliance examination of the unit's Comprehensive Annual Financial Report (CAFR) or financial reports if there is no published CAFR. The LGC receives a copy of the auditor's report and has to approve the final auditor payment upon submission of billing information (N.C.G.S. 159-34a).

To assist auditors with compliance information, the state provides a checklist of general statute requirements which include both accounting and financial reporting criteria that encompasses more than 200 items under N.C.G.S. 159. The checklists have a vast array of areas which includes the generally accepted accounting principle (GAAP) compliance which can provide indication to internal control questions and thus lead to a reassessment of financial stability.

Under the guidelines of the RFP, auditors are provided with a specified sequence in which to examine financial documents that identify many of the common errors found among statements such as unrecorded liabilities and issues with accounts payables, overestimation of revenues, improper computation of state aid claims, etc. (Rousmaniere, 1980). Initially, general purpose statements such as a working balance sheet for each fund, working statement of revenues, expenditures, and transfers for each fund, and the Management Discussion \& Analysis (MDA) are submitted to the auditor. Second, there is an examination of cash and investment practices which includes bank reconciliations and a detailed list of issues related to payables such as outstanding checks by account number, etc. Third, there is an examination of receivables including lists of unpaid tax bills, outstanding fund receivables, outstanding service receivables, and a schedule of miscellaneous receivables. Fourth, the amounts of capital assets are determined through the provision deposition lists as well as acquisition lists and the verification that the unit has balanced the Capital Asset subsystem to the government-wide statements. Finally, transactions involving long-term debt are analyzed which include the debt schedule for each debt issue, payment transfers, and a compilation of vested vacation schedules (NCDST, 2007).

\subsection{Factors Influencing Note Disclosure Irregularities}

Note disclosure reporting among audits illuminates some of the more specific transactions that take place during the fiscal year. For the most part, reporting errors are the result of either simple oversight or some deviation from a change in GASB requirements. However, there are some factors within the process that can be influential in reducing the number of errors. As mentioned earlier, the procurement of audit services in North Carolina is rather extensive. This is not unusual since findings have indicated most states require local governments to issue a RFP for audit services (Wardlow and Friar, 1989). Interestingly enough, findings from a previous study of NC 'white letters' found that specific reporting problems among counties were more likely to be found when counties have another selection method besides the traditional Request for Proposal (RFP) (Modlin, 2012). On a similar note, Modlin \& Stewart (2014b) found increased satisfaction with county audits when county staff made the final selection of the auditor (AUDITFINAL).

Previous studies have determined that the county manager is highly influential in the budget process (Modlin, 2011b). Additional findings confirm that increased county manager involvement (CMAUDIT) in the audit process leads to increased audit satisfaction (Modlin \& Stewart, 2014b). Based on this finding, it is expected that increased county manager involvement in the audit process will lower note disclosure errors, thus a negative coefficient.

The vast majority of accounting functions are located within the finance department in professionally administered governments. In these cases, the role of the finance officer is critical since the finance officer not only has oversight of daily accounting functions, but also the entire audit process. More experienced finance officers (EXPERFIN) with educational foundations in accounting (FIELDFIN) were found to have higher levels of satisfaction with county financial audits compared to finance officers with less experience. Moreover, this same study found that increased satisfaction with the audit was a resultant of increased satisfaction with the 
auditor governmental accounting (GOVACC) skills (Modlin \& Stewart, 2014b). With the continual complexities of local government finance including the many financial statements submitted during the audit process, an increased number of local government staff (STAFF) dedicated to the audit process has proven to be influential in auditee satisfaction (Modlin \& Stewart, 2014b).

Many GASB standards require various operating transfers in and out (NETOP) of the general fund for purposes related to specific payables and receivables. In many cases, this is related to human service use or debt service payments. In other situations, the budget ordinance can determine the legality of the transfers. While many of the transfers are covered within the statement of revenues, expenditures and changes in fund balance, the asset amounts listed in the government wide statements may not reconcile. Non disclosure of specific transfers, especially those related to enterprise funds, have been found to alter general fund balance requirements, and in some cases, these enterprise fund deficits that require transfers can be a precursor to long-term fiscal problems (Modlin, 2010; Modlin \& Stewart, 2014a).

Complex transaction activity as mentioned above has a number of steps that enable auditors to easily monitor the entire process to ensure all journal transactions and ledger postings are accurate. However, the rather routine transactions of smaller capital purchases such as buildings, land, automobiles, that take place through the primary bank as basic installment purchases (IP) can easily be omitted due to the speed of the transaction and the timing of financial statement disclosure. A higher number of these transactions are expected to influence the number of note disclosure findings.

Timely audit reporting to the state oversight body (LATE), if required, has become customary as a result of increased accountability surrounding local government finances. Findings have suggested that delayed or late audits are associated with a higher quality audit (Brown and Margavio, 1994; Deis and Hill 1995). Additional findings of increased fees associated with the time and resources used in the audit and the expectations of receiving the Government Finance Officers Association Award (GFOA) for financial reporting are also related to audit delay (Johnson, 1998). In North Carolina, if there are additional costs associated with being a continued GFOA reward recipient, the LGC recommends the additional costs should be included in the RFP (NCDST, 2007).

\section{Data and Methods}

Analyses of note disclosures based on the variables in question required two streams of data. First, survey data was used to obtain information concerning auditor solicitation (RFP), involvement of various staff members (CMAUDIT, AUDITFINAL, STAFF), experience and field of the finance officer (EXPFIN, FIELDFIN), and audit punctuality (LATE). The survey instrument was also used to determine how the finance officer assessed satisfaction with the auditor's governmental accounting expertise (GOVACC), which was based on a five point scale with ' 5 ' representing the highest level of satisfaction with auditor skill level. Usable responses were returned from $54 \%$ of North Carolina finance officers.

The remainder of the data was obtained from the North Carolina Local Government Commission and was in specific reference to 2009 audit findings (NETOP, IP). A special request was made for county 'white letters' which contained the findings for the note disclosures (NOTES), the primary dependent variable in the study and also a discrete variable. All of the discrete variables are measured on a five point scale. Table 1 below provides a description of all variables used in the study. 
Table 1. Definitions of variables for measurement

\begin{tabular}{|c|c|}
\hline Variable & Measurement \\
\hline NOTES (Dependent) & Number of reported errors within note disclosures; $5=$ Five or More \\
\hline $\begin{array}{l}\text { GOVACC } \\
\text { (Dependent) }\end{array}$ & $\begin{array}{l}\text { Extent to which finance officers are satisfied with auditor governmental accounting } \\
\text { expertise; } 5=\text { Very Satisfied }\end{array}$ \\
\hline RFP & Dummy variable for auditor selection method; RFP $=1$ \\
\hline AUDITFINAL & Dummy variable for final decision on auditor selection; Elected Official(s) = 1 \\
\hline CMAUDIT & $\begin{array}{l}\text { Extent to which finance officer stated county manager audit involvement; } 5=\text { Very } \\
\text { Involved }\end{array}$ \\
\hline EXPERFIN & Discrete measure for finance officer experience; $5=$ More than 20 years \\
\hline FIELDFIN & Dummy variable for finance officer field of expertise $1=$ Accounting \\
\hline STAFF & $\begin{array}{l}\text { Discrete measure for the number of staff assigned to the audit process; } 5=\text { More than } \\
\text { five }\end{array}$ \\
\hline NETOP & $\begin{array}{l}\text { Dummy variable for net change in operating transfers at end of fiscal year } 1=\text { Positive } \\
\text { inflow }\end{array}$ \\
\hline IP & Discrete variable for installment purchase expenses $5=$ More than $100 \mathrm{M}$ \\
\hline LATE & Dummy variable for prompt audit submission to state oversight agency; $1=$ On Time \\
\hline
\end{tabular}

In order to determine contributing factors that determine note disclosure reporting errors, separate logistic regression models were estimated. In the primary model, the dependent variable (NOTES) was constructed as a discrete variable in accordance with the number of note disclosure errors as cited by the LGC with ' 5 ' representing five or more issues that required either more information or an exhibit change. The primary model appears as follows:

$$
\begin{gathered}
\text { NOTES }=\text { Bo }+ \text { BIRFP }+ \text { B2AUDITFINAL }+ \text { B3CMAUDIT }+ \text { B4EXPERFIN }+ \text { B5FIELDFIN }+ \text { B6STAFF }+ \\
\text { B7NETOP }+ \text { B8IP }+\beta_{9} \text { LATE }
\end{gathered}
$$

A secondary model was constructed to determine finance officer satisfaction with auditor governmental accounting expertise (GOVACC) used as the dependent variable and therefore tested against the same set of predictors. Governmental accounting expertise has been utilized in prior studies in order to determine auditee satisfaction on some kind of level (Samelson, Lowensohn, and Johnson, 2006: Modlin \& Stewart, 2014b). In this study, the variable is mainly to provide some overall guidance to generalize the findings.

\section{Findings}

This study provides both an insight into note disclosure reporting errors as well as

an examination into various factors which can contribute to potential error disclosure. Initial findings from the 2009 fiscal year suggest that a majority of county governments within the state had some form of reporting error among financial statement notes. In an analysis of the descriptive statistics, county governments in North Carolina had an average of about 1.66 reporting errors; however, finance officers appeared to be fairly satisfied with the governmental accounting expertise of the external auditor. Approximately three county staff members were involved in the audit process with the county manager having only a moderate level of involvement (2.28). Most counties within the study used some form of RFP for solicitation, but the final decision on an auditor was either made unilaterally by staff or as a collective with commissioners. 
Table 2. Descriptive statistics: overall sample ( $\mathrm{N}=54)$

\begin{tabular}{lccc}
\hline \multicolumn{1}{c}{ Variable } & Mean & Standard Deviation & Range \\
\hline NOTES & 1.66 & 1.77 & $0-5$ \\
GOVACC & 4.55 & .775 & $1-5$ \\
CMAUDIT & 2.28 & 1.16 & $1-5$ \\
STAFF & 3.14 & 1.51 & $1-5$ \\
EXPFIN & 2.56 & 1.47 & $1-5$ \\
IP & 2.08 & 1.50 & $1-5$ \\
& Mode & & Range \\
RFP & 1 & & $0-1$ \\
AUDITFINAL & 0 & & $0-1$ \\
FIELDFIN & 1 & & $0-1$ \\
NETOP & 0 & & $0-1$ \\
LATE & 1 & & $0-1$ \\
\hline
\end{tabular}

Note disclosure reporting errors for fiscal year 2009 appeared to more prominent among smaller counties (Table $3)$. The vast majority of problems were missing notes associated with the lack of an appropriate pension note accompanying the Other Postemployment Benefit (OPEB) note. This type of note can include information concerning other forms of insurance coverage such as life, health, vision, and hearing. Governments typically make cash payments to these retirement funds on a pay-as-you-go basis rather than on an up-front basis due to other financial obligations. In most of the cases, the LGC maintained the OPEB note was necessary if a material payroll was present. In one of the smaller counties with a budget of less than $25 \mathrm{M}$, the OPEB had not been calculated nor recorded. LGC staff responded by providing an example of a pay-as-you-go-note. In another case, the county government had an OPEB recording error liability of more than $55 \mathrm{~K}$ that was actually counted twice against the annual costs incurred by the county.

The importance of long-tem debt issues were also associated with the net pension obligations for law enforcement option for special separation allowances (LEO). In one county, nearly $400 \mathrm{~K}$ was not reported as a long-term obligation. This obligation is also funded on a pay-as-you-go basis and there is a requirement for notes to include a paragraph on the funding progress of these allowances. For reporting purposes, the LEO cannot be combined with the OPEB.

Complexities involving debt disclosure were also fairly abundant. Most cited counties had to ensure that outstanding debt was required to reconcile with LGC records. In any case, there is the requirement that the notes be inclusive of individual bond description issues, leases, and/or non-bonded debt with additional information for original issue date, original issue amount, terms of issuance, purpose of debt, and provider of funds if non-bonded debt. More clarity was also requested if there were other intergovernmental agencies involved in county debt activities. In some cases, the United States Department of Agriculture (USDA) would assist counties with capital projects, which was usually associated with countywide water projects, and in those cases, the LGC would request only information in which the USDA was not involved.

Reconciliation issues were the overall problem with cash and investment reporting. County government government-wide cash and investment records plus any cash and investments carried in fiduciary funds must materially equal the cash and investments disclosed in the deposits and investments note. Two counties had a reminder stating that the only investments that were allowed are those stipulated by state statute (N.C.G.S. 159-30). The importance of this is due to risk and collateralization issues. In one case, more clarification was needed for a money market fund and this same county had a shortage of $\$ 744 \mathrm{~K}$ in the government wide statements compared to the notes on cash and investments. 
Table 3. Auditor findings by budget size and note disclosure errors

\begin{tabular}{|c|c|c|c|c|c|c|}
\hline Total $(n=54)$ & OPEB & $\begin{array}{l}\text { Law Enforcement } \\
\text { Option }\end{array}$ & $\begin{array}{l}\text { Debt } \\
\text { Service }\end{array}$ & $\begin{array}{l}\text { Cash } \\
\text { Statements }\end{array}$ & $\begin{array}{l}\text { Risk } \\
\text { Disclosures }\end{array}$ & $\begin{array}{l}\text { Fund } \\
\text { Transactions }\end{array}$ \\
\hline \multicolumn{7}{|l|}{ Budget Size } \\
\hline$>25 \mathrm{M}(\mathrm{n}=15)$ & 8 & 4 & 7 & 4 & 4 & 1 \\
\hline $25-50 M(n=16)$ & 11 & 2 & 2 & 3 & 1 & 5 \\
\hline $50 \mathrm{M}-75 \mathrm{M}(\mathrm{n}=5)$ & 2 & 2 & 0 & 1 & 0 & 1 \\
\hline $\begin{array}{l}75 \mathrm{M}-100 \mathrm{M} \\
(\mathrm{n}=9)\end{array}$ & 3 & 2 & 3 & 4 & 2 & 0 \\
\hline $\begin{array}{l}\text { More than } 100 \mathrm{M} \\
(\mathrm{n}=9)\end{array}$ & 6 & 2 & 3 & 2 & 1 & 1 \\
\hline
\end{tabular}

The risk disclosures discuss county preparation for a variety of incidents which could have serious financial consequences. The LGC primarily required more transparency within risk management notes that disclose how risk is addressed, the extent of coverage for liability and fidelity bonds, and past significant claims. In addition, information should be included on flood insurance coverage (for counties with a Federal Emergency Management classification of ' $A$ '). The expansion of stewardship notes were also requested of certain counties for fund deficits in non-major funds, and in one case, an expansion for a Department of Social Services Director that was serving temporarily at that time as the finance officer.

Note disclosure statements of fund statements provide a more thorough analysis of governmental activities. Some counties had to include descriptions of the major funds, internal service funds, and the fiduciary funds, which are a required part of the notes and further meet GASB 38 standards. For a couple of counties, there was the request for note disclosures to have the business-type activities segregated by fund with a further breakdown of the business-type activities' capital assets to the enterprise fund level. In addition, there was a further request to break out the portions that were related to water and sewer.

Table 4. Regression analysis using an ordered logit model to determine risk disclosure attributes

\begin{tabular}{lcc}
\hline \multicolumn{1}{c}{ Variable } & Coefficient & Odds Ratio \\
\hline RFP & .9613 & 2.6152 \\
\hline AUDITFINAL & $-1.6646^{* *}$ & .1893 \\
CMAUDIT & $-.6576^{*}$ & .5181 \\
EXPERFIN & -.1378 & .8713 \\
FIELDFIN & $1.5060^{* *}$ & 4.5083 \\
STAFF & $.4229^{*}$ & .6552 \\
NETOP & .4256 & 1.5305 \\
IP & .0347 & 1.0353 \\
LATE & -.5532 & .5752 \\
Threshold 1 & -2.3490 & \\
Threshold 2 & -2.1228 & \\
Threshold 3 & -.8243 & \\
Threshold 4 & .2748 & \\
$N$ & 47 & \\
Log Lik. & -50.5165 & \\
LR Chi-squared (9) & $17.28^{* *}$ & \\
McFadden's Pseudo- $R^{2}$ & 0.1460 & \\
\hline
\end{tabular}

Notes: Cell entries are unstandardized parameter estimates. (Numbers in parentheses are odds ratios.)

${ }^{* *} p \leq .05 ; * p \leq .10$ (two-tailed test). 
Table 4 presents an ordered logit model with predictors that have some influence on the number of note disclosure errors reported by the LGC. Several of the predictors were found to be influential in determining note disclosure error findings with finance officer background (FIELDFIN) as having the most influence. Finance officers with an accounting background were 4.5 times more likely to have an increased level of note disclosure errors within their audits compared to finance officers with other backgrounds. The other major finding was associated with the final decision on auditor selection. When the final decision concerning auditor selection was made by either staff or a combination of staff and elected officials (AUDITFINAL), reporting errors increased. However, the odds ratio suggests that the increase in errors would be modest under these circumstances.

The findings also suggested that the varying degrees of input by key personnel do influence reporting errors. A less involved county manager (CMAUDIT) in the audit process seemed to suggest a slight increase in reporting errors. Conversely, as more county staff (STAFF) were assigned to the audit process, there was a higher likelihood of note disclosure errors. However, the odds ratio suggested little change if there were less people involved in the audit. A test of the full model with all 9 predictors against a constant-only model was statistically reliable $X^{2}(9, \mathrm{~N}=47)=17.28, p \leq .005$, indicating that the predictors, as a set, reliably distinguish between the different levels of reporting errors.

Table 5. Regression analysis using an ordered logit model to determine satisfaction with auditor governmental accounting expertise

\begin{tabular}{lcc}
\hline \multicolumn{1}{c}{ Variable } & Coefficient & Odds Ratio \\
\hline RFP & .5752 & 1.7774 \\
AUDITFINAL & -1.0305 & .3568 \\
CMAUDIT & $1.0238^{* *}$ & 2.7840 \\
EXPERFIN & .3856 & 1.4705 \\
FIELDFIN & -.2313 & .7935 \\
STAFF & -.0926 & .9116 \\
NETOP & $.4256^{*}$ & 4.9564 \\
IP & 1.6001 & 1.0061 \\
LATE & $2.8688^{* *}$ & 17.6162 \\
Threshold 1 & .6744 & \\
Threshold 2 & 1.7116 & \\
Threshold 3 & 4.1575 & \\
Threshold 4 & & \\
$N$ & 47 & \\
Log Lik. & -31.6287 & \\
LR Chi-squared (9) & $18.55^{* *}$ & \\
McFadden's Pseudo- $R^{2}$ & 0.2268 & \\
\hline Notes: Cell entries are unstandardized parameter estimates. (Numbers in parentheses are odds ratios.) \\
$* * p \leq .05 ; * p \leq .10$ (two-tailed test). & & \\
\end{tabular}

The primary dependent variable in the study could have altering interpretations of county finance office staff expertise. Therefore, an additional model was created to test the predictors against finance officer overall perception of auditor governmental accounting expertise. A couple of the variables had interesting findings. First, as county manager involvement in the audit process increased, there was the expectation of at least a 2.78 increase in the log odds of placement in a higher level of satisfaction. The other interesting finding had a direct impact on both auditor quality and satisfaction. Finance officers were more than 17 times likely to have higher satisfaction with the auditor's governmental accounting expertise if the audit was submitted to the LGC in a timely manner. The model was significant at the .05 level and some researchers actually do acknowledge McFadden's Pseudo- $R^{2}$ statistics between .2-.4 as is the case with this model (Hensher and Johnson, 1981). 


\section{Implications}

This type of study has many policy implications from both an internal and external perspective. From an administrative standpoint, the findings alone point to the need for extended clarification of government finance practices. For example, proper computation of OPEB benefits is critical for both retired and current employees with the continual escalation of costs associated with retirement. As noted within the findings, one county did not have this information recorded. In general, it is important for all government units to decrease the unfunded actuarial accrued liabilities (UAAL) as much as possible.

The study has also illuminated the need for all levels of management to have some involvement in the process. The findings suggested that additional participation by the manager can lead to lower note disclosure errors in addition to more input into the selection of the auditor by elected officials. For the manager, more involvement in the audit process can further provide comprehensive understanding of all revenue streams as well as ledgers that have the most associated expenses. Additional manager involvement is also useful for more specific questions regarding proposed budget presentations and higher credit rating applications.

The implementation of state oversight, as illustrated with this study, has proven pivotal in sustaining fiscal stability among local governments (Modlin, 2010). In this case, the LGC actually evaluates the audit and provides instruction to the county in order to have a more coherent exhibit. The use of a state oversight body to analyze county audits further clarifies the actual financial position of the unit. Most states that have oversight usually have general ratios without the depth of fund analyses.

External policy implications are also evident within the study. A comprehensive audit with transparent financial notes that properly correlate with all statements is important for an increase in bond rating. The lower interest rates associated with a higher bond rating provide the opportunity for much needed capital projects that may otherwise be unaffordable with more traditional long-term debt alternatives. Also from an external standpoint, quality vendors and contractors are more likely to submit bids for services to financially stable governments that are solidified by audits that substantiate that position.

Notes to the financial statements provide additional importance for citizens as well. The notes not only discuss general financial features of the government itself, but also specific funding types. For example, this study had findings that had alternative forms of debt omitted from the notes (more than $\$ 3 \mathrm{M}$ in one case). If this information had been negated entering the next fiscal year and depending on the amount and how it affected fund balance, commissioners in this county could have been in the unenviable position of weighing tax increase alternatives to alleviate the shortfall.

\section{Conclusion and Limitations}

This exploratory study provided a much needed insight into the importance of notes to the financial statements or note disclosures. A model was created which examined variables that contributed to the number of note disclosure errors. More involvement of elected officials in the auditor selection process, a more involved county manager, and finance officers with more diverse training were all significant in reducing the number of note disclosure errors. However, the discussion on the different forms of note disclosure errors had the most profound findings. This information illuminated the importance of note disclosures and the profound consequences associated with the nondisclosure of particular statement and fund activity. In this case, the lack of OPEB reporting was the primary reporting problem among county governments.

There are several limitations to the study. First, the heavy state oversight mechanism in place significantly enhances accountability among county governments in the study. The LGC summarizes the errors and in some cases even provide illustrations for correction as in the case of the law enforcement option for special separation allowance (LEO). Many states do not enforce annual audit legislation much less have an oversight organization which ensures financial stability through an examination of the accounting processes. Second, the number of retired personnel for each county along with law enforcement personnel may have provided more insight into the OPEB and LEO findings. The utilization of these statistics as variables could have created additional significant relationships. Third, the background of the staff preparing the audit was not available. The presence of a full-time staff accountant, especially among mid-size counties, would probably greatly reduce note disclosure errors. Finally, information was not available concerning the unilateral decision making of finance officers. Counties with smaller staffs have to rely significantly more on the finance officer and thus all decisions concerning journal entries and ledger postings encompass that decision making component.

Overall, it can be concluded that a quality audit with few note disclosure errors can be achieved with the assistance of several employees at all levels of the government unit. The findings did suggest that there was a 
relationship between finance officers with an accounting background and an increase in note disclosure errors, but this can attributed to a couple of reasons. First, a majority of finance officers do have an accounting degree therefore substantially increasing the odds of having counties in the study with multiple errors. This form of training, or at least an accounting background, does provide the best training for the complexities of journal entries, ledger posting, fund management, etc. (Modlin, 2011a). Timing could be the origin of these issues if the transactions occurred after the exhibits had been submitted to the auditor. Second, many finance officers with accounting were trained using private sector examples. Various fund management, capital project financing and debt issuance, changes in GASB requirements, and state audit guidelines provide for more complex accounting and reporting. It must be pointed out that after many years of research, it can be concluded that finance officers in North Carolina do an exemplary job in budget sustainability, cash management, accounting process implementation, and transparency placement in reporting (Modlin, 2011a; Modlin, 2012; Modlin \& Stewart, 2014b).

\section{References}

Brown, K., \& Margavio, T. (1994). Audit Costs of Small Cities in an Unregulated Market Environment. Public Budgeting and Financial Management, 6(3), 376-421.

Cahill, A. G., \& James, J. (1992). Responding to Municipal Fiscal Distress: An Emerging Issue for State Governments in the 1990s. Public Administration Review, 52(1), 88-94. http://dx.doi.org/10.2307/976554

Coe, C. K. (2007). Preventing Local Government Fiscal Crises: The North Carolina Approach. Public Budgeting and Finance, 27(1), 39-49. http://dx.doi.org/10.1111/j.1540-5850.2007.00879.x

Coe, C. K. (2008). Preventing Local Government Fiscal Crises: Emerging Practices. Public Administration Review, 68(4), 759-767. http://dx.doi.org/10.1111/j.1540-6210.2008.00913.x

Deis, D., \& Hill, R. (1995). Further Evidence on Simultaneous Equations Analysis of the Quality Control Review Process, Engagement Fees, and Audit Timeliness. (Unpublished paper). Baton Rouge, LA: Louisiana State University.

Gauthier, S. (1989). Audit Management Handbook. Chicago, Illinois: GFOA.

Groves S. M., \& Valente, M. G. (2003). Evaluating Financial Conditions: A Handbook for Local Government. Washington, D.C.: International City/County management Association.

Hensher, D. A., \& Johnson, L.W. (1981) Applied Discrete-Choice Modeling. London, UK: Croom Helm.

Holder, W. (2004). Financial Accounting, Reporting, and Auditing. In J. R. Aronson \& E. Scwartz (Eds.), Management Policies in Local Government Finance (5th ed., pp. 207-222). Washington, D.C.: International City/County Management Association.

Honadle, B. W. (2003). The States' Role in U.S. Local Government Fiscal Crises: A Theoretical Model and Results of a National Survey. International Journal of Public Administration, 26(2), 1431-1472. http://dx.doi.org/10.1081/PAD-120024405

Honadle, B. W. (2004). Fiscal Health for Local Governments: An Introduction of Concepts, Practical Analysis and Strategies. New York, NY: Elsevier Press.

Ives, M., Patton T. K., \& Patton S. R. (2013). Introduction to government and Not-For-Profit Accounting (7th ed.). Boston, Mass.: Pearson Prentice Hall.

Kloha, P., Weissert, C. S., \& Kline R. (2005). Someone to Watch Over Me: State Monitoring of Local Fiscal Conditions. The American Journal of Public Administration, 35(3), 236-255. http://dx.doi.org/10.1177/0275074005277435

Lawrence, D. (1994). Financing Capital Projects in North Carolina (2nd ed.). Chapel Hill, NC: Institute of Government, the University of North Carolina at Chapel Hill.

Modlin, S. (2010). Rationalizing the Local Government Decision Making Process: A Model for State Oversight of Local Government Finances. Public Performance \& Management Review, 33(4), 13-39. http://dx.doi.org/10.2753/PMR1530-9576330403

Modlin, S. (2011a). The Declining Use of Internal Service Funds: How Local Governments Are Changing The Allocation of Indirect Costs. Journal of Public Budgeting, Accounting \& Financial Management, 23(2), 151-165.

Modlin, S. (2011b). Who Really Runs County Government? The County Manager in the Budget Formulation 
Process. Public Administration \& Management, 16(12), 21-45. Retrieved from http://www.spaef.com/file.php?id=1312

Modlin, S. (2012). County Government Finance Practices: What Independent Auditors are Finding and What Makes Local Government Susceptible. Journal of Public Budgeting, Accounting \& Financial Management, 24(4), 558-578.

Modlin, S., \& Stewart, L. (2014a). Determining County Government Fiscal Instability: Independent Audit Report Findings and the Prompting of State Action. Journal of Public Budgeting, Accounting \& Financial Management, 26(3), 405-428.

Modlin, S., \& Stewart, L. (2014b). Staff Involvement in the External Audit Process: Reassessing Independent Auditor Satisfaction Levels Among Professionally Administered County Governments. Public Administration Quarterly, 38(2), 243-269.

North Carolina Department of State Treasurer Local Government Commission. (2007). Technical Memorandum No. TM-80-02. Raleigh, NC.

Rousmaniere, P. F. (1980). Local Government Auditing - A Manual for Public Officials. New York: Council on Municipal Performance.

Ruppel, W. (2010). Government Accounting Made Easy (2nd ed.). Hoboken, New Jersey: John Wiley \& Sons.

Samelson, D., Lowensohn, S., \& Johnson, L. (2006). The Determinants of Perceived Audit Quality and Auditee Satisfaction in Local Government. Journal of Public Budgeting, Accounting \& Financial Management, 18(2), 139-166.

Wardlow, P., \& Friar, S. (1989). Local Government Procurement of CPA Audit Practices: The Role of the States. Public Budgeting \& Finance, 9(1), 92-106. http://dx.doi.org/10.1111/1540-5850.00812

\section{Copyrights}

Copyright for this article is retained by the author(s), with first publication rights granted to the journal.

This is an open-access article distributed under the terms and conditions of the Creative Commons Attribution license (http://creativecommons.org/licenses/by/4.0/). 